Ann. Génét. Sél. anim., I977, 9 (3), 30I-306.

\title{
Polymorphism of egg white proteins egg weight and components weight in the Fayoumi hen
}

\author{
A. OBEIDAH, P. MÉRAT et L. DURAND \\ Laboratoire de Génétique factorielle $\left(^{*}\right)$ \\ Centre national de Recherches zootechniques, I.N.R.A., \\ 78350 Jouy-en-Josas
}

\section{Summary}

The genetic variations in egg-white proteins were detected in Fayoumi eggs. $\mathrm{G}_{2}$ locus proved to be the only polymorphic among four egg-white protein loci investigated. Two types were determined, $G_{2} A B$ and $G_{2} B B$. The heterozygote proved to have heavier eggs and accordingly heavier egg components. The phenotypic correlation, with respect to the homozygote type, between albumen weight and yolk weight proved to be insignificant.

\section{Introduction}

Egg-white contains a number of proteins, which have been investigated by many workers for existence of genetic variants detected by electrophoresis. Polymorphism of some egg-white proteins has been investigated in relation to embryonic mortality (MORTON et al., I965). Other works have been done, recently, concerning possible association with the economical traits (BUVANENDRAN, V., I967; Titok, I. G., I970; Kovalen Ko et al., I972; LazUk, Makarova, I976; Stratil, VONDREJEC, I973 and MARTINKEVITCH et al., I974). The first investigator (BUVANENDRAN, I967) found an association between body weight, egg weight and ovalbumin; the AA genotypes were heavier and laid heavier eggs than the two other genotypes. On the other hand, for $G_{3}$ globulin, the heterozygotes laid more egg than either homozygote, but $\mathrm{G}_{2}$ seemed to have no effect on the characters studied. He added, that selection on gene basis is not practical. MartiN-

(*) This work had been done in collaboration between " Laboratoire de Génétique Factorielle CNRZ, Jouy-en-Josas, France and the Animal Breeding Department, Faculty of Agriculture, Cairo University, Egypt. 
KEVITCH et al. (I974) found a significant effect of genotypes on egg production for $G_{2}$ locus.

This study had the purpose to determine the genetic variations in the eggwhite proteins of Fayoumi eggs. Moreover, if polymorphisms in egg-white proteins would exist, it was thought of interest to know if this has some bearing on egg weight and weights of its components.

\section{Material and methods}

The eggs tested in this study were transported to France from Egypt; they came from the Fayoumi breeding stock of the Experimental Poultry Breeding Farm, Faculty of Agriculture, Cairo University. The flock was hatched in winter 1976. All birds were kept on floor under the same environmental conditions and fed the same rations at lib. The total number of individual hens used is $7 \mathrm{I2}$; they are the progeny of 20 sires. One egg per hen was collected in january 1977. Each egg corresponding to each hen was broken and yolk was separated from albumen. Yolk and shell (with membrane) were weighed to the nearest mg. Meanwhile, a sample from egg-white had been taken from each egg. Albumen weight was obtained by difference between egg weight and both yolk and shell weight.

Electrophoretic analysis, using starch gel (LUsH, I96I; CroIZIER, I969). was practiced, firstly, to detect ovalbumin variants, but all eggs tested proved to be homozygote to this locus (AA type). The same holds true for conalbumin and $G_{3}$, which were of $B B$ and $A A$ types. The only polymorphism detected in this investigation was for $G_{2}$.

The weights of eggs and egg components were compared on within sire and dam pairs according to the genotypes. An analysis of variance was made on this material with genotype (at $G_{2}$ locus) and sire as sources of variation.

\section{Results and discussion}

Two types were determined at locus $G_{2}$ as shown in Figure $I, B B$ and $A B$ types. The number of $\mathrm{BB}$ hens was 580 vs $132 \mathrm{AB}$ hens. No AA individuals were found. Gene frequency computed for $\mathrm{A}$ is $9.3 \%$ and for $\mathrm{B}$ is $90.7 \%$. Comparing observed and expected numbers in the random mating hypothesis gives a significant $\chi^{2}$ of 7.39 for 2 d.f. $(P<.025)$. The absence of AA birds may suggest some disadvantage attached to this genotype.

The mean values, for egg weight, yolk weight, shell weight and albumen weight obtained for the homozygote $\left(\mathrm{G}_{2} \mathrm{BB}\right)$ are in grams $37.69, \mathrm{r} 2.55,4.28$ and 20.89 respectively and $40.27, I_{3} .40,4.63$ and 22.24 respectively for the heterozygote $\left(\mathrm{G}_{2} \mathrm{AB}\right)$. The differences between the two genotypes are all in favor of AB: $2.55 \mathrm{~g}$. for egg weight, $0.85 \mathrm{~g}$. for yolk weight, $0.35 \mathrm{~g}$. for shell weight and $1.35 \mathrm{~g}$. for albumen weight. As egg weight is determined by its components weights, relatively, the largest difference is due to albumen weight. The differences between the two genotypes within each sire for the four characters confirm the overall genotype effect (Table I). They are in the same direction with only two exceptions (slight difference in the reverse direction) for egg, yolk and albumen 


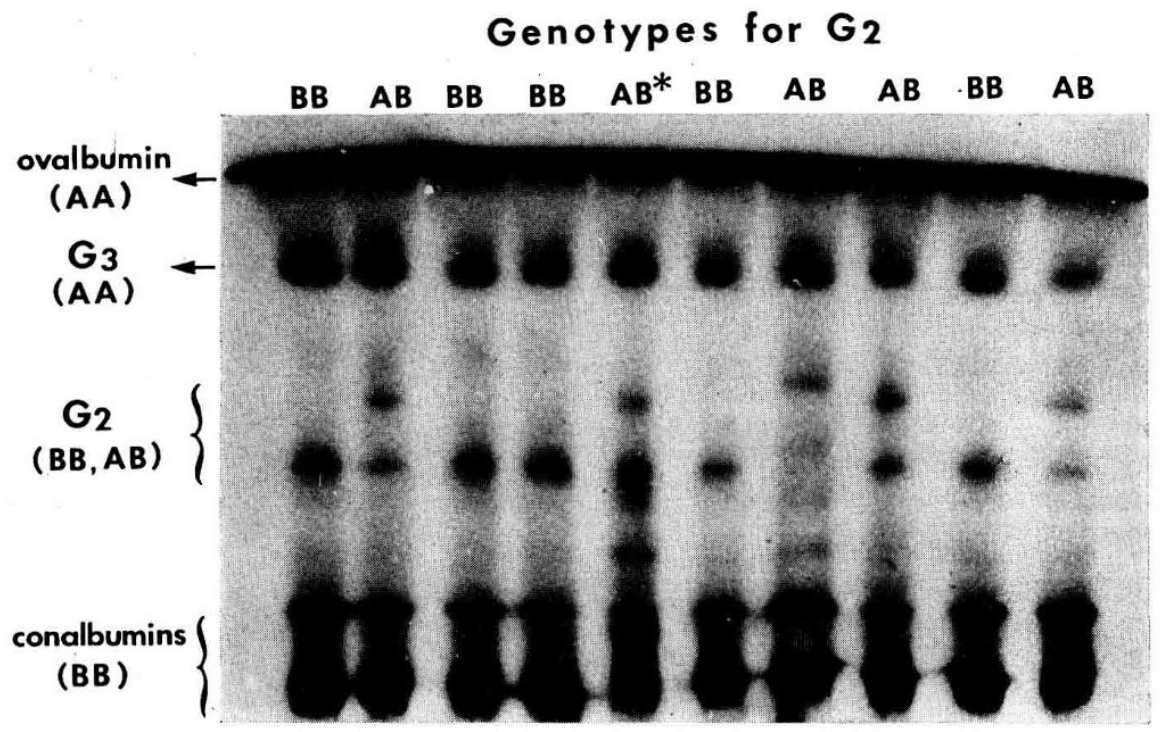

Fig. I. - A Starch gel plate of Fayoumi egg albumen proteins. Electrophoretic analy'sis.

* (This sample is one of Jouy eggs for comparing to our eggs.)

Une plaque en gel d'amidon des protéines du blanc d'œuf de Fayoumi. Analyse électrophorétique.

weight and three for shell weight. The percentage of the four differences from the corresponding homozygotes weights, are: 6.8 per cent for egg weight, 6.8 per cent for yolk weight, 8.2 per cent for shell weight and 6.4 per cent for albumen weight; This may indicate the superiority of the heterozygote type. OBeidah and Mostageer (unpublished data) obtained a genetic correlation of 0.8 between shell weight and shell thickness. The higher percentage for shell weight may be in favor of a higher shell thickness for the heterozygote. Such results on egg components do not seem to have been reported previously in the literature: MARTIN KEVITCH et al. (I974) reported a significant effect of $\mathrm{G}_{2}$ locus for egg production in white Leghorn. TITOK (I970) found that the homozygotes of $G_{3}$ and $G_{2}$ types were the best ones for both productivity and fertility in comparison with the two respective heterozygotes.

The analysis of variance for the four traits is shown in Table 2 . There are no interactions between sires and genotypes for the four traits. The variation between the two genotypes proves to be highly significant in all cases. The variation between sires for shell weight is the only case which proved to be insignificant. Comparing the variances between sires and between genotypes, the first one is about one fifth of the second for egg weight, more than one four th for yolk weight and albumen weight and about one tenth for shell weight. This indicates, that the variations in egg weight and components weights are due in large proportion to the genotypes, while the sire effect is relatively of less contribution. This is quite apparent in the case of shell weight. On the other hand, the variance attributable to this locus, approximately, is $\mathbf{1 . 0 3 2}$ for egg weight; as a fraction of the additive genetic variance, which is 2.32 , it is 44.4 per cent. Thus selection for egg weight on basis of this gene is convenient or/and may be used in deciding the choice of lines and the mating systems. 


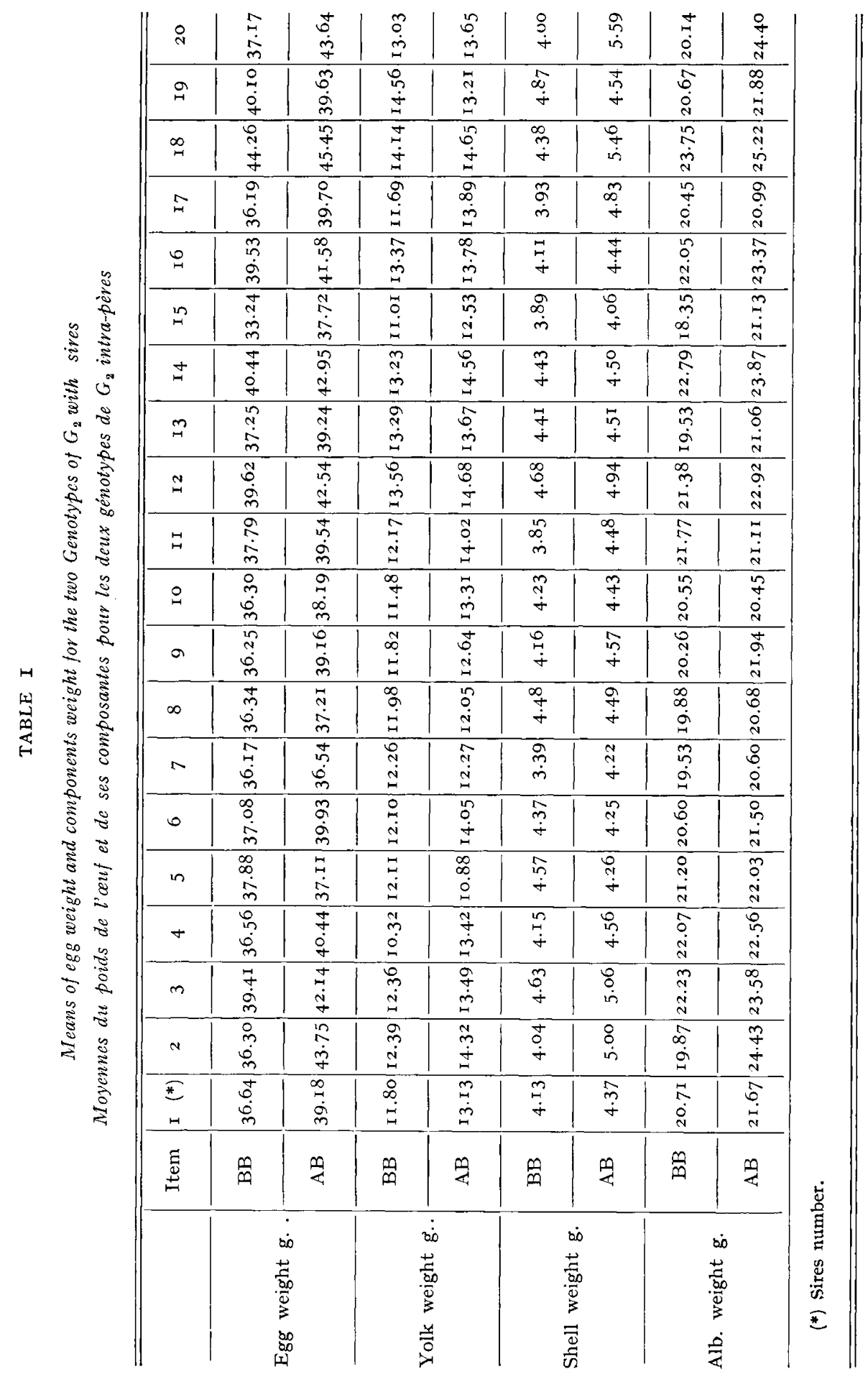


TABLE 2

Analysis of variance for egg weight and components weights.

Analyse de variance pour le poids de l'aut et de ses composantes

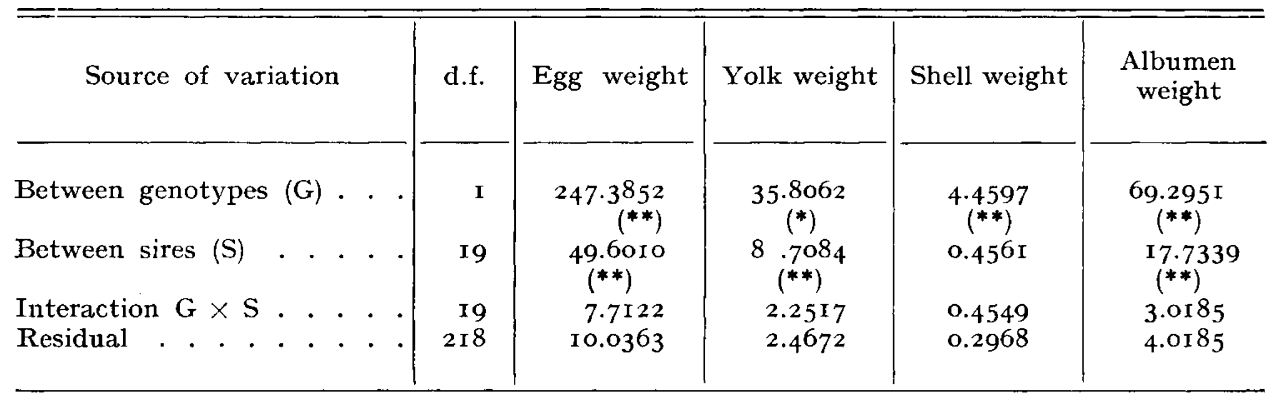

(**) Significant at I p. Ioo level.

(*) Significant at $5 \mathrm{p}$. roo level.

The phenotypic correlations between the four characters, with respect to each genotype, are presented in Table 3. Correlations obtained for the homozygote type are of lower magnitudes than the figures obtained for the heterozygote. The most distinguishable figure is that between yolk weight and albumen weight which is 0.126 for the homozygote. This may add to the superiority of the heterozygote if selection is done on yolk/albumen ratio.

\section{TABLE 3}

Correlations (I) between the four characters studied with respect to each genotype.

Corvélations entre les quatre caractères étudiés à l'intérieur de chaque génotype

\begin{tabular}{|c|c|c|c|c|c|}
\hline & & Egg weight & Yolk weight & Shell weight & Albumen weight \\
\hline $\begin{array}{l}\text { Egg wt . } \\
\text { Yolk wt. } \\
\text { Shell wt. } \\
\text { Albumen wt }\end{array}$ & . $\cdot$ & $\begin{array}{l}0.655\left({ }^{* *}\right) \\
0.6 \mathrm{I} 8\left(^{* *}\right) \\
0.8 \mathrm{I} 7(* *)\end{array}$ & $\begin{array}{c}0.778\left({ }^{* *}\right) \\
\ldots \ldots \ldots \ldots \ldots \\
0.395{ }^{(* *)} \\
0.126\end{array}$ & $\begin{array}{c}0.668\left({ }^{* *}\right) \\
0.43^{(* *)} \\
\ldots \ldots \ldots \ldots \ldots \\
0.37^{(* *)}\end{array}$ & $\begin{array}{r}0.870\left(^{(* *)}\right. \\
0.393\left(^{* *}\right) \\
0.504(* *) \\
\ldots \ldots \ldots \ldots\end{array}$ \\
\hline
\end{tabular}

(I) $\mathrm{N}=$ I29 for each genotype.

Above the diagonal is the heterozygote type and below is the homozygote.

(**) Significant at $\mathrm{r}$ p. roo level.

(*) Significant at 5 p. roo level. 


\section{Résumé}

\section{Polymorphisme des protéines du blanc d'cuf, poids de l'œuf et de ses composantes chez la poule Fayoumi}

Les variants génétiques des protéines de l'albumen ont été recherchés dans des œufs de Fayoumi. Le locus $\mathrm{G}_{2}$ s'est révélé être le seul polymorphe parmi quatre loci étudiés. Deux types ont été identifiés, $\mathrm{G}_{2} \mathrm{AB}$ et $\mathrm{G}_{2} \mathrm{BB}$. Les œufs des poules hétérozygotes sont plus lourds et leurs fractions composantes (blanc, jaune, coquille) le sont également. Parmi les individus homozygotes, la corrélation phénotypique entre le poids de l'albumen et le poids du jaune n'est pas significative.

\section{References}

Buvanendran, V., I967. Egg-white polymorphisms and economic characters in domestic fowl. Br. Poult. Sci., 8, I19-129.

Croizier G., 1969. Etude du polymorphisme des protéines de l'albumen chez Gallus Gallus $L$. Thèse, Faculté des Sciences de l'Université de Paris.

Kovalenko V. P., Kromin V. S. and Bendarenko U. V., I972. Polymorphism of avian egg globulins with respect to genetic differentiation of strains and productivity level. Genetika, 8 (II), 52-62.

LazUK V. I., and Makarova Z. N., I976. (Biochemical polymorphism of egg-white in different lines of domestic fowl.) in A.B.A., 44 (6), 330 .

Lush I. E., I96r. Genetic polymorphism in the egg albumen proteins of the domestic fowl. Nature, Lond., 189, 98I-984.

Martinkevich, I. S., Fokina Z. V., Belov A. M., Dranitaa S. N., and Bogdarov L. V., I974. (Biochemical polymorphism of egg proteins in White Leghorns crosses 444 and Enia). in $A . B . A$., $42(9), 465$.

Morton J. R., Gilmour D. G., McDermid E. H., and Ogden A. L., 1965. Association of blood group and protein polymorphism with embryonic mortality in the chicken. Genetics, Princeton, 51, $97-107$.

Stratil A. and VON DREJC, J., r973. The relationship between polymorphic proteins of hen's egg-white and egg production. Zivocisna Vyroba, 18, 571-576.

Tıток I. G., I970. (Genetic polymorphism of globulins of egg protein and its connection with the productivity of Leghorn White hen.) Tsitol. Gen., 4 (6), 49I-494. 